

Citation:

Jones, B and Beresford, S (2014) Leeds and the Northern Arts Prize. Journal of Place Management and Development, 7 (3). 247 - 258. ISSN 1753-8335 DOI: https://doi.org/10.1108/JPMD-11-20120040

Link to Leeds Beckett Repository record:

https://eprints.leedsbeckett.ac.uk/id/eprint/1224/

Document Version:

Article (Updated Version)

The aim of the Leeds Beckett Repository is to provide open access to our research, as required by funder policies and permitted by publishers and copyright law.

The Leeds Beckett repository holds a wide range of publications, each of which has been checked for copyright and the relevant embargo period has been applied by the Research Services team.

We operate on a standard take-down policy. If you are the author or publisher of an output and you would like it removed from the repository, please contact us and we will investigate on a case-by-case basis.

Each thesis in the repository has been cleared where necessary by the author for third party copyright. If you would like a thesis to be removed from the repository or believe there is an issue with copyright, please contact us on openaccess@leedsbeckett.ac.uk and we will investigate on a case-by-case basis. 


\section{Leeds and the Northern Arts Prize}

\section{Brian Jones and Shirley Beresford}

Leeds Business School, Leeds Metropolitan University, UK

\section{Correspondence Address:}

Dr Brian Jones,

Leeds Business School,

Leeds Metropolitan University,

The Rose Bowl,

Portland Gate,

Leeds,

United Kingdom,

LS1 3HB

$\mathbf{T}+44(0) 1138124632$

E b.t.jones@leedsmet.ac.uk 


\section{Abstract}

\section{Purpose}

This paper looks at the nature of the relationship between the marketing of the contemporary visual arts, cultural tourism and city and urban regeneration. This exploratory study of the marketing of the contemporary visual arts in Leeds has as its background narrative the emergence of Britart.

\section{Approach}

The growth of contemporary visual arts provides the context for a case study of the Northern Art Prize, which was first awarded in 2007.

\section{Findings}

The study found a number of factors for success that can aid urban renewal and city regeneration. Private sector marketing expertise levered into the management of the project was one critical success factor. Another was that private sector funding freed up marketers and artists and allowed risk taking. Participants highlighted a lack of vision for the contemporary visual arts in the city and region and a strong desire for new collaborative working and new governance structures for the delivery of arts marketing and cultural tourism.

\section{Value}

The Northern Art Prize offers much for the marketing of contemporary visual arts, cultural tourism, city branding and urban renewal. Investing in and marketing of the arts is argued to serve as a stimulus that can bring a range of benefits for the business and wider community. Marketing, especially arts marketing, can help deliver social, economic and urban regeneration. 
Keywords - Leeds, marketing, contemporary visual arts, Britart, urban regeneration, tourism

Paper type - Case study

\section{Introduction}

Within the academic (Byrne, 1989; 2001), policy (OECD, 2006) and practitioner communities (Northern Art Prize, 2012) there is ongoing debate about the strategies; policies and practices that can best deliver social and economic development. Renewing and regenerating cities and urban areas are a continuous process and one that requires funding but also the use of innovation, imagination and creativity. Understanding, interpreting and making sense of the urban environments in which we live is increasingly being done through art and it can be used to include as well as exclude (Sharp, Pollock and Paddison, 2005). Art helps citizens of cities frame, occupy, enjoy and challenge the spaces in which they live, work and play. It can be used to help challenge urban blight and to increase social capital and create a sense of community well being (Semenza, 2003).

This paper examines the marketing of the contemporary visual arts in Leeds via a case study of the Northern Art Prize. It operates at the intersection between and interface that is arts marketing and city branding and place management. Analysing the nature of the relationship between arts marketing and the marketing of the contemporary visual arts in particular with place, place branding and city and urban regeneration makes for an interesting theoretical move. 
The research reported on here is relevant to the academic research, policy and practitioner communities. This paper looks at the use of visual art in cultural tourism marketing and the use of arts marketing to support city and regional cultural tourism and destination branding (Blain, Levy and Ritchie, 2005; Hankinson, 2007). In addition it looks at these issues in the context of city and urban regeneration; and economic and socio-cultural renewal as part of a bigger programme of local economic development. It furthers understanding of the activities described broadly as 'arts marketing', and "place branding". It reports on qualitative primary data gathered from key stakeholders in Leeds working in art, tourism, economic development and arts marketing. Attitudes and current thinking towards cultural tourism and its implications for the marketing of the arts and place are explored. The paper begins with a brief overview of city and urban renewal and the role of art in that process. It then offers a brief overview of BritArt before moving on to an account of the Northern Art Prize. The research approach is then detailed, findings outlined and conclusions are drawn.

\section{City and Urban Renewal}

The role of art in urban regeneration has long been a subject of academic debate (Hall and Robertson, 2001). In recent years successive UK governments have argued policy on 'culture' should be linked clearly to social outcomes (Ridge et al, 2007). The policy debate on culture has increasingly been aligned with and measured by social and economic outcomes. Whether or not such a policy shift is desirable or not is open to debate. From a policy perspective social and economic outcomes increasingly set and frame the debate on art and culture. Urban regeneration, social inclusion, enterprise, engagement with hard to reach audiences, cultural tourism, access for young people and those with a disability have all been linked with a cultural theme (Ridge et al, 2007).

O'Connor et al (2007) argue that the creative landscape of the North East and indeed the whole of England, has changed dramatically in recent years. Working with a range of public 
and private sector partners Arts Council England in the North East have generated significant investment in world-class infrastructure for the arts. Capital investment has given the River Tyne new buildings such as the BALTIC and the Sage in Gateshead, the installation of the Angel of the North sculpture, and a growing national and international reputation, which is best reflected in the hosting of the World Summit on Arts and Culture in 2006 (Arts Council England, 2006). Public Art capital projects such as the Angel of the North in Gateshead or the Middlesbrough Institute of Modern Art were deemed politically desirable and acceptable as measurable outputs were linked to regeneration initiatives and acted as one strand of economic and social policy for areas often suffering multiple deprivations. Leeds has, it can be argued, lost out and is now playing catch up with the development of the Northern Art Prize by focusing some of its marketing resources in the area of contemporary art. The Northern Art Prize is intended to help Leeds compete in the cultural and place branding stakes with other northern English cities such as Manchester, Newcastle and Liverpool.

Economic and industrial decline visited Leeds in the 1970s and 1980s. As traditional manufacturing industries, such as textiles and clothing manufacture closed, social and urban decay set in. Leeds City Council's regeneration team (Leeds City Council, 2012), Yorkshire Forward (Yorkshire Forward, 2006) the central government funded Regional Development Agency and other bodies, for example Marketing Leeds (2012), have in the course of the past 30 plus years striven to bring about economic, social and urban renewal. A number of arts and culture based initiatives have run including for example, the Leeds St Valentine's Fair (Harcup, 2000). Leeds has been particularly successful at reinventing itself and repositioning its offering as the regional capital of the Yorkshire and Humber. In recent years Leeds has been subject to a process of gentrification (Dutton, 2003). Today Leeds has a well-established legal and financial services sector (Yorkshire Forward, 2006); is renowned for its retail and shopping experiences (Jones and Temperley, 2011); and still retains a successful manufacturing base (Yorkshire Forward, 2006). Marketing has played an 
important role in this transformation from city and urban decline through to renewal and renaissance (Marketing Leeds, 2012). Re-branding, re-positioning and the role of place have served to deliver much needed change in bringing about social, cultural and economic uplift for Leeds and the wider region. Cities such as Newcastle-Gateshead have used the arts for example Baltic, Sage and the Angel of the North as totemic evidence of successful urban regeneration and economic renewal. The story of Leeds efforts to reposition its offering through marketing of the contemporary visual arts and the Northern Art Prize is worth telling for what it reveals about the competitiveness of cities, the changing nature and role of art in society; and central to all of this is the deconstruction and greater understanding of the complex concept of place.

Marketing and tourism agencies for Leeds and wider Yorkshire region have an important role to play in delivering endogenous economic growth and community and social uplift. Cultural tourism and the contemporary visual arts aid business and employment growth and have value adding potential. A number of organizations including Marketing Leeds and the Yorkshire Tourist Board are influential and active in promoting the contemporary visual arts for the Yorkshire and Humber region and Leeds in particular. Amongst other organizations, Arts Council England provides the strategic policy overview of arts marketing for the region. Stakeholders includes public, private and voluntary sector visual arts organisations who host arts events and exhibitions; Marketing and Public Relations Agencies who have worked in the arts sector and have experience of destination marketing campaigns; policy makers in the regional tourism agencies; networking organisations whose main mission statements are to market the arts for the region and city collectively; and individual arts supporters such as sponsors, enthusiasts, and artist promoters. Many have common and overlapping objectives of policy and strategy. One role of contemporary visual arts and cultural tourism is to support the social agendas of regeneration and social inclusion. 
Little attention has been given in either academic, policy or strategy terms to a discussion of the marketing of the contemporary visual arts in the City of Leeds in a cross disciplinary way. A major study by O'Connor et al (2007) provides a useful 'snapshot' of general broad insights into 'cultural activities' up to 2007. In the Yorkshire region much policy orientated applied research has been undertaken in recent years within the public sector around cultural tourism, visual arts and destination branding (see appendix A). Increasingly policy makers and marketers specialise in areas such as tourism, urban regeneration, social exclusion or audience development and this has potential for creating difficulties in making recommendations beyond a narrow area. Making connections, seeing the bigger picture and avoiding silo thinking regards public policy prescription can only be of benefit to all concerned.

The city and region are looking to new ways of positioning the destination brand through the arts. City branding is a growth area of academic research (Dinnie, 2010). The external image of cities is increasingly linked to a cultural profile and the creation of distinctive urban vision. Increasingly this vision is a combination of a cultural checklist that includes galleries, concert halls, shopping brands, architecture, arts festivals and events (Urry, 1994). The Northern Art Prize has been one of the most high profile events of its type in this sector and provides the base for a particularly apposite case study. However, it is necessary to begin with a brief review of the story of BritArt as this provides the background context from which the Northern Art Prize emerged. It is against the BritArt background that the Northern Art Prize should be situated, explored and understood.

\section{BritArt}

Marketing of contemporary visual arts of necessity requires a brief discussion of the state of the UK art market. The UK's BritArt movement has come to dominate the contemporary visual arts market in the last twenty plus years. Artists such as Damien Hirst, Tracey Emin 
and the Chapman brothers have become international art celebrities, galleries such as White Cube, the Saatchi, Tate Modern, and international art fairs such as Frieze have made Britain, especially London, the recognised international home of cutting edge, world leading modern art. These galleries, exhibition spaces, art events and personalities typified by the Young British Artists have come to dominate the UK art scene. Areas such as Hoxton and the East End serve as examples of London's 'art regenerated' areas (Collings, 1999). Britart was a name given to a group of contemporary conceptual artists, painters and sculptors, and installation artists based almost exclusively in London many of whom attended Goldsmiths College.

In 1988 a group of artists led by Damien Hirst, organised an exhibition called Freeze (later re-titled Frieze) in an affordable alternative warehouse space that established the artistrun/artist as a curator approach to exhibiting (Collings, 1999). These events produced little press exposure but did nevertheless prove to be the genesis of the Britart movement. Charles Saatchi, contemporary art collector and co-founder of the Saatchi and Saatchi advertising agency promoted the Young British Artists exhibitions and became their main collector. By mid 1990's Saatchi was the acknowledged main sponsor of Britart, a name he invented for a series of shows, which became the iconic work of British art in the late $20^{\text {th }}$ century. Britart was the symbol of contemporary art worldwide and Saatchi's highly professional communications skills and resources ensured strong media coverage and international marketing of the art product. Moreover, the 'celebrity artist' was promoted to new heights in a media hungry environment (Collings, 1999).

Britart revitalised a whole generation of contemporary art galleries and spaces and events. Frieze Art Fair (2012) and the growth of new or revitalised publications such as Art Monthly (2012) and Art Review (2012) all contributed to the marketing of the art produced over that period. The Sensation Show at the Royal Academy in 1997 and Tracey Emins Turner Prize in 1999 bore testimony to Britart's acceptance by the art 'establishment'. Although the 
opening of the Tate Modern in 2000 did not provide any major accolade for the Young British Artists their clear inclusion was another affirmation of their embryonic status within the art community.

Attendance by the art buying publics at auctions and art fairs of contemporary art (Britart and now new global markets) were still very buoyant in 2008. But as the full extent of the global financial and economic crisis developed between 2008 and 2011, the contemporary art market became sensitive to changes but remained outwardly confident. Contemporary art has economic and social benefits and within the UK it has a strong London base. The UK regional response has yet to be properly documented. The international response to contemporary visual arts is positive with, for example, the opening of White Cube in Hong Kong in 2011 (Tsui, 2011). Britart has proven to be a creative, value adding export industry for UK plc.

\section{The Northern Art Prize}

Launched in 2007 the Northern Art Prize represents the only competitive prize and exhibition of its type and status in the north or England. Research into arts marketing and cultural tourism, and the use of the Northern Art Prize as a new marketing tool for the arts, is original, current and a story worth telling. Moreover it is story that needs to be told for what it tells us about the arts, the ways in which they are perceived and how they connect with the business community and wider society.

The Northern Art Prize comprises a number of different stakeholder partners. The prize was co-founded by Logistik and Leeds City Council. Partners include the artists panel of judges drawn from acknowledged arts experts, the Leeds Art Gallery and Museum (owned and run by Leeds City Council), the sponsors of the prize (Logistik, ARUP, Arts and Business), and agencies involved in marketing and promotion (Anita Morris Associates). 
"The prize has emerged from a partnership between Logistik, a design and communications agency, Leeds City Council and Arup, the global firm of designers and consultants." (Northern Arts Prize, 2012)

The Northern Art Prize has quickly established itself as the main vehicle for the competition and exhibition of contemporary artists for the North of England. Logistik, Leeds City Council, Arup and minthotel sponsor the award, which was launched in 2007 at Leeds Art Gallery. There is $£ 16,500$ of prize money for the winning contemporary artist (Northern Arts Prize, 2012). The award is open to any artist that is North of England based, irrespective of the sort of work produced. The winner could be a sculptor, painter or installation artist. The prize serves as a clear example of the business and arts communities working together to deliver added value through social and economic outcomes.

The stated aim of Logistiks support for the prize is highlighted in the event brochure: "By supporting the arts in the region we can build the North as a place of creative excellence. We made this commitment to nurture and reward creativity in the region and to encourage links between the arts and the business communities." (Northern Art Prize Exhibition Brochure, 2007).

Leeds City Council, ARUP and Arts and Business Yorkshire are also partners for the prize. The Northern Art Prize Exhibition is hosted in the City Art Gallery on Leeds Headrow, a publicly funded Leeds City Council gallery. Leeds City Council's intended objectives in being partners it states in the exhibition promotional literature (Northern Art Prize Exhibition Brochure 2007), is to 'promote the wealth of arts in the North of England as well as helping to develop emerging artists which add to the rich cultural life the city'. ARUP (Northern Art Prize Exhibition Brochure 2007), an international professional services company, supports the prize to 'highlight the importance of diverse and inclusive culture to the continuing 
renaissance of northern cities.' Finally, Arts and Business Yorkshire (Northern Art Prize Exhibition Brochure 2007) describes its involvement as to 'help business people support the arts and the arts inspire business people, because good business and great art together create a richer society.' This says a lot about private and public sector support for the arts. The underlying narrative and sub-text to public arts discourse is very much about art as cultural symbolism; a figurative representation of economic, business, societal and urban regeneration. It also tells us a lot about collaboration and partnership working and it illustrates well the importance of place, city and regional branding.

\section{Research Approach}

The case study approach adopted here is used to explore a specific geographically located art event in a specific arts sector. Using the case study method gives the opportunity to explore issues in a setting that is spatially and temporally restricted. The research combined qualitative in depth face-to-face interviews and questionnaires with analysis of secondary data from the contemporary visual arts and cultural tourism. A number of data gathering methods were used and included in-depth interviews; emailed questionnaires; secondary data analysis; and industry reports. The research participants represented the key senior stakeholders in the contemporary visual arts eco-system, and the main cultural tourism marketing policy and strategy bodies.

Two stakeholder groups were interviewed and questioned. The first were arts professionals and included artists, curators, and exhibitors. The second were marketers, marketing and Public Relations agencies. The individuals selected were deemed most appropriate for the research process because of their backgrounds in, and knowledge of arts and cultural tourism marketing at management level within organisations. They share certain characteristics and experiences that were important to the development of the research 
(Daymon \& Holloway, 2011). Individuals within organisations from the following broad groups were chosen for the sample:

- $\quad$ Art Marketing practitioners

- $\quad$ Cultural Tourism Marketing practitioners

- $\quad$ Sponsors

- $\quad$ Arts and artist professionals

Due to the specialist nature of the research topic, there were only a small number of individuals with the experience and knowledge able to assist with the research process. Interview participants were concentrated within the Yorkshire/Leeds region. Overall sixteen out of twenty targeted participants from arts and marketing organisations completed the questionnaires or returned detailed feedback and responses. In addition to this three participants provided telephone responses and four in-depth qualitative interviews were undertaken. Research participants included managers in the contemporary visual arts and cultural tourism management as well as those working in arts marketing policy and strategy. Primary research interview data with key players in the Leeds arts marketing and cultural tourism stakeholder group is used to enrich and inform the findings. For the purposes of confidentiality interviewees are not identified and are referred to alphabetically as participants $A, B, C$ and so on.

\section{Findings}

A clear theme to emerge from the interviews relating to current arts marketing is that arts organisations and public sector funded marketing agencies largely adopted a media relations perspective to their marketing activity. The tools and techniques adopted by publicly funded arts organisations were rooted in a promotional approach to 
communications, lacking often strategic planning or use of contemporary marketing thinking on experiential marketing or use of contemporary social media techniques. For Leeds, marketing practice for the visual arts appears rooted in a simplified media relations activity which ignores the potential national or international nature of the Northern Art Prize for tourists.

\section{Beauty contests}

In areas of policy participant $\mathrm{K}$ stated, 'Leeds and the region is beginning to use the excellence of existing cultural offer to market the area. Leeds is the major hub of performing arts scene in region and plans for an arena and improved, restored, cultural facilities means Leeds is catching up with other cities.' Here it is interesting to note the observation made by other stakeholders that the cultural tourism offer is largely based or defined in the performing arts rather than the contemporary visual arts. It is also worth noting the nature of competition between cities for inward investment and policy prescriptions designed to arrest decline and deliver social and economic regeneration. The nature of competition between cities has, it can be argued, descended into little more than a beauty contest. This beauty contest between cities can help raise standards and be a driver of innovation and change in delivering economic development. It can also advantage some areas to the detriment of those denied this economic and social lever. Such beauty contests typically compete for central government and European funding to deliver public policy initiatives. Central government and European funding is limited in terms of available capital and in terms of the purposes to which it can be used. Funding is also restricted with regards to cities and regions that are on a number of socio-economic indicators deemed to be deprived enough to qualify for public funding. The beauty contest fails to take account of the fact that some cities and regions are more beautiful than others by virtue of private sector developments and the practices of business clustering. Success it would seem breeds success. The city and regional beauty contest is distorted by virtue of historical circumstance, nation state status 
within the UK, central UK government policies, economic policies, private sector developments and social and economic change.

\section{$\underline{\text { Cultural tourism }}$}

The role of cultural tourism as an engine of regeneration is noted not only by policy-making participants but also by contemporary visual arts organizations. Participant $\mathrm{J}$ argued that, "The role of arts/culture is very important in giving cities their identities and plays a key part in attracting visitors, tourists and businesses. It's important because it brings investment into the city and therefore growth.'The role of contemporary visual arts in promoting cultural tourism was acknowledged by participant G, 'The promotion of Leeds and Yorkshire nationally and internationally as a destination for contemporary visual arts potentially benefits all organisations in the sector.'The limitations of the contemporary visual arts was also highlighted, as participant D commented, 'The contemporary visual arts form a significant element in cultural tourism marketing of all major European cities but Leeds does not seem to capitalise on what it's got.' Participant C spoke of the limitations of the public sector audience development agendas in limiting the development of cultural tourism; 'We need to be much more sophisticated about the tourist market. It's still quite old fashioned marketing of Yorkshire. About landscapes and traditional Yorkshire values. So in that respect Harewood House is much easier to market.'Commenting on the Northern Art Prize and target audiences' participant A stated, 'The idea would be to have lots of cultural tourists coming to Leeds. It's about raising the profile of Northern Artists to a national and international audience. If we can try and encourage the general public to go and see contemporary visual arts, that would be fantastic. Unless your space is accessible and welcoming, it is probably quite intimidating unless you are an art tourist. It's about making people feel welcome as it's a destination venue.'Participant A asked, 'Who wants to live in a city full of shops and bars which exclusively caters for a young upwardly mobile audience? Where are your families, elderly, people who don't drink in bars? People don't want to feel pressure to spend money - just to chill out and enjoy it - no pressure to consume. For 
tourism market Leeds has a reputation for shopping and bars, this may take time to change to include arts.'

\section{Co-ordination}

Many participants expressed the view that the city and region lacked joined-up thinking on the cultural tourist offer and the role of contemporary visual arts within it. Participant B stated, "All of the marketing agencies for Leeds don't talk to each other. They are not joined up in any way." Criticism of the doubling up of administration and squandering of resources that are seen as scarce also compound this as participant B explained; 'They (marketing stakeholders) are doubling up on administration - why don't they restructure and have one administration for a vision?' Participant $\mathrm{J}$ agreed that there is ' No co-ordinated approach to the contemporary visual arts in Leeds'.

There was almost overwhelming agreement that a collective strategic approach to marketing the contemporary visual arts as part of a cultural tourism offer would help achieve artistic and government objectives for inclusion, access, and regeneration and wealth creation. Engaging with and reaching out to hard to reach groups was acknowledged to be somewhat problematic, as participant C stated, 'A lot of the agendas in marketing are driven by local concerns. We are driven by an access agenda - getting those segments of Leeds that don't have motivated populations, to come to museums and galleries.' Most participants thought that the contemporary visual arts could play a significant role in cultural tourism marketing for European cities but were disappointed Leeds was not following such a strategy. Some linked this to a perception of a lack of confidence in the contemporary visual arts sector by public sector funding bodies and their ability to deliver, despite European and international examples to the contrary. Participant $\mathrm{J}$ stated, 'Leeds and to a certain extent Yorkshire is still perceived as parochial and the contemporary visual arts suffer from this. But although Leeds likes to think it's a leader it isn't in the visual arts and it lags behind most other northern cities.' 
Solutions to these problems and issues were diverse but covered a few key areas. Most participants stressed the need for adequate and appropriate funding and resources for the successful development of the contemporary visual arts. The development of marketing expertise within organisations was also recognised as an issue and a desire for marketing freedoms and creativity was expressed.

Many participants expressed the opinion that there was little leadership for the contemporary visual arts in a marketing or cultural tourism sense and a vacuum existed in the co-ordination of effort in terms of marketing vision, strategy and implementation. This vacuum was not seen to be filled by the recognised agencies responsible for the generic 'marketing of Leeds or Yorkshire' by arts organisations and many felt a gap was apparent between the rhetoric of policy statements and action.

\section{Conclusions}

This paper has explored the nature of the relationship between marketing of the contemporary visual arts, specifically the Northern Arts Prize and place, i.e. Leeds. It has looked at how marketing of the contemporary visual arts support cultural tourism for Leeds and the Yorkshire region, and illustrated this via a case study of the Northern Art Prize. A number of lessons are drawn from this study. Communication is critical to the success of the Northern Art Prize and the range of stakeholders involved necessitates on the one hand the need for a consistent clear message, but at the same time different stakeholders require different messages based on their particular role in the event.

No sophisticated level of marketing evaluation for the contemporary visual arts and cultural tourism beyond a generic tourist grouping was apparent in the secondary research or 
through primary sources at this stage in the development of the contemporary visual arts sector in Leeds. Other than visitor lists to special previews, visitor numbers to exhibitions and special attendee events organised by the Public Relations agency engaged there was little data available which suggests a gap in research into the evaluation of contemporary visual arts in Leeds. Received wisdom suggests visitor figures for the gallery during the Northern Art Prize exhibition period was higher than usual year on year. However, the regional or national pull for the Northern Art Prize has not been fully evaluated. The limited resources provided by private sector sponsorship support were almost entirely used for publicity, Public Relations and promotional activity. Leeds City Council has no dedicated or ring fenced resources for evaluation of the Northern Art Prize. Evaluation should be undertaken to ensure delivery of value for money and for impact assessment purposes.

It was agreed by most participants in the study that in recent policy frameworks Leeds and Yorkshire lacked vision or even scenario planning for international or even European potential for cultural tourism and the contemporary visual arts. A 'what would success look like' visioning for the contemporary visual arts for the region seemed distant although highly desirable. One of the key findings of the primary research was the consistent message from participants for the desire for greater co-ordination and collaboration of effort on matters of arts marketing and tourism. An unexpected conclusion drawn from the research was the finding that a key characteristic of the contemporary visual arts activity in Leeds was a female dominated network of actors. The 'in crowd', wittily described by some participants as the 'cliterati' of Leeds, dominates the contemporary visual arts and cultural tourism sphere of influence.

Placing contemporary visual arts into a cultural tourism framework still appears a conceptual step too far for many of the key marketing agencies in tourism for the region and city. A number of key policy documents such as the Yorkshire Forward's Regional Economic Strategy (2006) discuss cultural tourism as a marketing priority. However, little recognition is 
given of the Northern Art Prize as a potential cultural platform for contemporary visual arts as a cultural tourism product. The Northern Art Prize is largely a privately funded event and although in partnership with Leeds City Council, the policy framework fails to acknowledge its potential, and traditional tensions and suspicions between public and private sector activity still prevails. This is reinforced by some participants' perceptions that the performing arts still remain closer to Leeds City Council funding priorities, and importantly is perceived as easier to justify to council taxpayers. Theatre building projects such as West Yorkshire Playhouse and Leeds Grand Lottery refit are 'tangible' and are very much about improving the built environment. In contrast contemporary visual art projects are less tangible, more ephemeral, and less building based.

Naming the exhibition at Leeds City At Gallery as the Northern Art Prize, was a quite deliberate, measured and skilful attempt to redefine the conceptual branding of Leeds beyond its geographic boundaries. In this respect this had been a successful initiative. The Northern Art Prize serves to demonstrate the benefits to be derived from private sector funding. In Leeds and the wider city region there is scope for greater private sector input into the marketing of the contemporary visual arts. The private sector role in contemporary arts ought to be encouraged and artists and partners in these sectors should have this as high priority in terms of their approach to marketing.

\section{Appendix A}

A series of public sector sponsored policy and strategy documents and reports have resulted and include:

- Yorkshire Forward (2005) Strategic Framework for the Visitor Economy. Yorkshire Forward, Leeds.

- Yorkshire Forward (2006) The Regional Economic Strategy for Yorkshire and Humber, 2006 - 2015 Yorkshire Forward, Leeds 
- Yorkshire Tourist Board (2007) Yorkshire progress in the Region Report, Executive Summary, Section: Culture, Leisure and Tourism Section 6.

- Yorkshire Forward (2008) Visitor Economy Strategy. Yorkshire Forward, Leeds

- Marketing Leeds, (2009). Marketing Leeds Business Plan 2009 - 2012, Cultural Sector Campaign, Marketing Leeds, Leeds

\section{References}

Arts Council England (2006) The World Summit on Arts and Culture, 14-18 June 2006, Newcastle Gateshead, England, The Report

http://www.worldsummitartsculture.org/files/FINALSummitreport.pdf?id=195 (Accessed 29 September 2012)

Art Monthly:

http://www.artmonthly.co.uk/ - accessed $29^{\text {th }}$ September 2012

Art Review:

http://www.artreview.com/ - accessed $29^{\text {th }}$ September 2012

Blain, C., Levy, S.E. and Ritchie, J.R.B. (2005) "Branding: Insights and Practices from Destination Management Organizations", Journal of Travel Research, Vol. 43, No. 4, pp. $328-338$

Byrne, D. (1989) Beyond the Inner City, Open University Press

Byrne, D. (2001) Understanding the Urban, Palgrave Macmillan 
Collings, M. (1999) This is Modern Art, London: Weidenfield and Nicolson

Daymon, C. and Holloway, I. (2011) Qualitative Research Methods in Public Relations and Marketing Communications, $2^{\text {nd }}$ edition, Oxon: Routledge

Dinnie, K. (2010) City Branding: theory and cases, Palgrave Macmillan

Dutton, P. (2003) "Leeds Calling: The Influence of London on the Gentrification of Regional Cities", Urban Studies, 2003, Vol. 40, No. 12, pp. 2557-2572

Frieze Art Fair:

http://www.friezeartfair.com/ - accessed $29^{\text {th }}$ September 2012

Hall, T. and Robertson, I. (2001) "Public Art and Urban Regeneration: Advocacy, claims and critical debates", Landscape Research, Vol. 26, No. 1, pp. 5-26

Hankinson, G. (2007) "The management of destination brands: Five guiding principles based on recent developments in corporate branding theory", Journal of Brand Management, Vol. 14 , pp. $240-254$

Harcup, T. (2000) "Re-imaging a post-industrial city: The Leeds St Valentine's Fair as a civic spectacle", City: analysis of urban trends, culture, theory, policy, action, Vol. 4, No. 2, pp. 215-231

Jones, B. and Temperley, J. (2011) Leeds Shopping Week: a case study, Journal of Place Management and Development, Vol. 4, Issue 3, pp. 272-281 
Leeds City Council (2012):

http://www.leeds.gov.uk/Business/Pages/Economic-Regeneration.aspx

accessed $22^{\text {nd }}$ September 2012

Marketing Leeds (2012):

http://www.marketingleeds.com/ - accessed $22^{\text {nd }}$ September 2012

Northern Art Prize Exhibition Brochure 2007, Leeds.

Northern Art Prize (2012):

http://www.northernartprize.org.uk/about - accessed 27th September 2012

O'Connor, J., Bell, D., Taylor, C. and Gonzalez, S. (2007) Yorkshire Cities and Culture, A Review of Current Thinking. University of Leeds

http://eprints.qut.edu.au/43863/1/Yorkshire cities and culture.pdf (Accessed 29 September 2012)

OECD (2006) Competitive cities in the global economy, Paris, OECD

Ridge, M., O'Flarherty, D, Caldwell-Nichols, A., Bradley, R., Howell, C., and Frontier Economics Ltd, London (2007) A framework for evaluating cultural policy investment, A Report Prepared for Department of Culture, Media and Sport (DCMS) May 2007 http://www.culture.gov.uk/images/research/Aframeworkforevaluatingculturalpolicyinvestment mainreport.pdf (Accessed 29 September 2012)

Semenza, J.C. (2003) "The Intersection of Urban Planning, Art, and Public Health: The Sunnyside Piazza". American Journal of Public Health, Vol. 93, No. 9, pp. 1439-1441. 
Sharp, J., Pollock, V. And Paddison, R. (2005) "Just Art for a Just City: Public Art and Social Inclusion in Urban Regeneration", Urban Studies, Vol. 42, No. 5-6 pp. 1001-1023

Tsui, E. (2011) UK gallery takes art to Chinese, The Financial Times, 18 July 2011, p. 8

Urry, J. (1994) "Cultural change and contemporary tourism", Leisure Studies, Vol. 13, No. 4, pp. $233-238$

Yorkshire Forward (2006) The Regional Economic Strategy for Yorkshire and Humber, 2006 - 2015. Yorkshire Forward, Leeds. 